\title{
CYTOTOXIC ACTIVITY OF BACTEROIDES GINGIVALIS AND BACTEROIDES ASACCHAROLYTICUS
}

\author{
T. J. M. van Steenbergen, M. D. den Ouden, J. J. A. Touw and J. De GraAff \\ Department of Oral Microbiology, Schools of Medicine and Dentistry, \\ Free University, PO Box 7161, 1007 MC Amsterdam, The Netherlands
}

\begin{abstract}
Summary. Culture filtrates of all eight strains of Bacteroides gingivalis and all five strains of $B$. asaccharolyticus were toxic for Vero cells. Cytotoxicity was in general greater with material from cultures of $B$. gingivalis than from $B$. asaccharolyticus but none of the culture filtrates from eight strains of $B$. melaninogenicus showed activity in this test. The toxic material was released during prolonged incubation and more detailed study of preparations from one strain indicated that it had a molecular weight of less than 3500 and was heat stable.
\end{abstract}

\section{INTRODUCTION}

The bacteroides of human origin that form black pigment are now allotted to one or other of three species. Representatives of Bacteroides melaninogenicus have been isolated from disease processes in the mouth (Spiegel et al., 1979) and from other sites (Smith, 1975; Finegold, 1977). B. gingivalis, which is composed of mainly oral strains that were formerly assigned to $B$. asaccharolyticus (Coykendall, Kaczmarek and Slots, 1980; van Steenbergen, Vlaanderen and de Graaff, 1981), seems to be very important in adult periodontitis (Slots, 1979; Spiegel et al., 1979; Tanner et al., 1979). The strains still classed as B. asaccharolyticus can be isolated from infections away from the mouth (Smith, 1975; Finegold, 1977). Little is known about the mechanisms of virulence of the black-pigmented bacteroides, although the action of collagenase was an early suggestion (Gibbons and MacDonald, 1961) and the organisms contain endotoxin (Hofstad, 1970). Eukaryotic cells maintained in culture have been useful indicators of cytotoxicity and this paper describes the results of testing material derived from representatives of three Bacteroides spp. on Vero cells, the continuous cell line derived from African green-monkey kidney cells.

\section{MATERIALS AND METHODS}

Bacterial strains. The micro-organisms used in this study were: B. gingivalis strains W83, W50 (Dr H. N. Shah, London Hospital Medical College, London), 376, 381, 382 (Dr S. S. Socransky, Forsyth Dental Center, Boston, USA), and H184, H185, H186 (our own isolates from patients with periodontitis); B. asaccharolyticus strains ATCC27067 and ATCC25260, and strains VPI4199, B536, B537 (Dr H. N. Shah); B. melaninogenicus subsp. melaninogenicus strains ATCC 25845, VPI9085, VPI9343, N334-71H (Dr H. N. Shah); B. melaninogenicus subsp. intermedius strains T588 (Dr H. N. Shah), ATCC25261, UJB 13a-c (Dr G. Sundqvist, University of Umea, Sweden), H187 (our own isolate from a patient with periodontitis); and Escherichia coli strain H10407 (Dr S. Falkow, University of Washington, Seattle). Strains were maintained by weekly subculture on blood-agar plates (Blood Agar Base No. 2; Oxoid, Basingstoke, Hants) containing horse blood ( $5 \% \mathrm{v} / \mathrm{v}$ ) haemin (BDH, Poole, Dorset) $5 \mu \mathrm{g} / \mathrm{ml}$ and menadione (Merck, Darmstadt, Germany) $2 \mu \mathrm{g} / \mathrm{ml}$. Cultures were grown in liquid BM medium (Shah et al., 1976) as described previously (van Steenbergen, de Soet and de Graaff, 1979) with and without glucose. 
Preparation of culture filtrates. Cultures, usually incubated anaerobically for 5 days at $37^{\circ} \mathrm{C}$, were then centrifuged at $3000 \mathrm{rpm}$ for $15 \mathrm{~min}$; the supernatant fluids were filtersterilised through $0 \cdot 45-\mu \mathrm{m}$ membranes (Millipore). Dilutions of these materials were made in $\mathrm{NaCl} 8.0 \mathrm{~g} / \mathrm{L}, \mathrm{KCl} 0.2 \mathrm{~g} / \mathrm{L}, \mathrm{Na}_{2} \mathrm{HPO}_{4} 1.15 \mathrm{~g} / \mathrm{L}, \mathrm{KH}_{2} \mathrm{PO}_{4} 0.2 \mathrm{~g} / \mathrm{L}$ at $p \mathrm{H} 7.35$ (PBS). The following dilutions were tested: 1 in 5,1 in 10,1 in 20,1 in 40 .

Cell-culture assay of toxin. Vero cells (Flow Laboratories, PO Box 17, Irvine, Scotland) were grown as monolayers at $37^{\circ} \mathrm{C}$ for 1 week in closed bottles in Glasgow's modification of Eagle's medium with $\mathrm{Na}_{2} \mathrm{CO}_{3} 2.75 \mathrm{~g} / \mathrm{L}$ but lacking glutamine (Flow Laboratories), and supplemented with fetal bovine serum ( $10 \% \mathrm{v} / \mathrm{v}$ ) (Flow Laboratories), vancomycin $500 \mathrm{mg} / \mathrm{L}$, gentamicin $20 \mathrm{mg} / \mathrm{L}$ and nystatin $5 \times 10^{4} \mathrm{U} / \mathrm{L}$ (GME medium). Toxic activity was assayed, essentially, as described by Speirs, Stavric and Konowalchuk (1977) in plastic dishes (Falcon 3008 ) with $0.6 \mathrm{ml}$ of Vero cell culture in each well. Almost confluent monolayers were used with $10^{5}$ Vero cells being seeded 2 days before use. Growth medium was then replaced by diluted culture filtrate or, in controls, by diluted BM medium. Cultures were then examined after incubation for $1-4$ days at $37^{\circ} \mathrm{C}$ in an atmosphere containing $\mathrm{CO}_{2}(5 \% \mathrm{v} / \mathrm{v})$. The proportion of cells affected was estimated directly or after staining of methanol-fixed cells with Giemsa $(10 \% \mathrm{v} / \mathrm{v})$ in PBS for $10 \mathrm{~min}$. The grading of the cytotoxic effects on the Vero cells was: +++ , more than $90 \%$ of Vero cells affected;,$++ 70-80 \%$ affected;,$+ 50-60 \%$ affected;, $\pm 30-40 \%$ affected; - , less than $20 \%$ affected.

\section{RESULTS}

Culture filtrates from all tested strains of $B$. gingivalis and $B$. asaccharolyticus caused a morphological change in Vero cells. The cytotoxic substance in filtrates from $B$. gingivalis strain W83 was studied in more detail. Vero cells grown for 1 or 2 days were used to study the effect; however, an almost complete monolayer was formed after 2 days and was easier to interpret. When a filtrate was diluted in GME medium, morphological changes of the Vero cells were observed but the cytotoxic effect was more obvious when PBS was used. Staining with Giemsa facilitated the observation of damaged cells, and this method was used for further studies.

In control cultures, only $5-10 \%$ of the Vero cells incubated with diluted sterile BM medium or with PBS alone were abnormal (fig. 1A). The effect of bacteroides culture filtrate

\section{TABLE}

Effect of diluted culture filtrates from B. gingivalis and B. asaccharolyticus strains on Vero tissue-culture cells after incubation for 2 days

\begin{tabular}{|c|c|c|c|c|}
\hline \multirow{2}{*}{ Strain } & \multicolumn{4}{|c|}{$\begin{array}{l}\text { Relative toxic effect* of culture } \\
\text { filtrate diluted } 1 \text { in }\end{array}$} \\
\hline & 5 & 10 & 20 & 40 \\
\hline $\begin{array}{l}\text { B. gingivalis } \\
\text { W83 } \\
\text { W58 } \\
381 \\
382 \\
376 \\
\text { H184 } \\
\text { H186 } \\
\text { H185 }\end{array}$ & $\begin{array}{r}+++ \\
+++ \\
+++ \\
+++ \\
+++ \\
+++ \\
++ \\
+\end{array}$ & $\begin{array}{r}+++ \\
+++ \\
+++ \\
+++ \\
+++ \\
+++ \\
++ \\
+\end{array}$ & $\begin{array}{r}+++ \\
+++ \\
+++ \\
+++ \\
+++ \\
+++ \\
+ \\
+\end{array}$ & $\begin{array}{r}+++ \\
+++ \\
+++ \\
+++ \\
+++ \\
+++ \\
\pm\end{array}$ \\
\hline $\begin{array}{l}\text { B. asaccharolyticus } \\
\text { ATCC25260 } \\
\text { B536 } \\
\text { ATCC27067 } \\
\text { VPI4199 } \\
\text { B537 }\end{array}$ & $\begin{array}{r}++ \\
++ \\
++ \\
++ \\
+\end{array}$ & $\begin{array}{r}++ \\
+ \\
+ \\
+ \\
+ \\
+\end{array}$ & $\begin{array}{l}+ \\
\pm \\
\pm \\
+\end{array}$ & $\begin{array}{l} \pm \\
- \\
- \\
-\end{array}$ \\
\hline
\end{tabular}

* See Materials and methods for grading of toxic effect. 

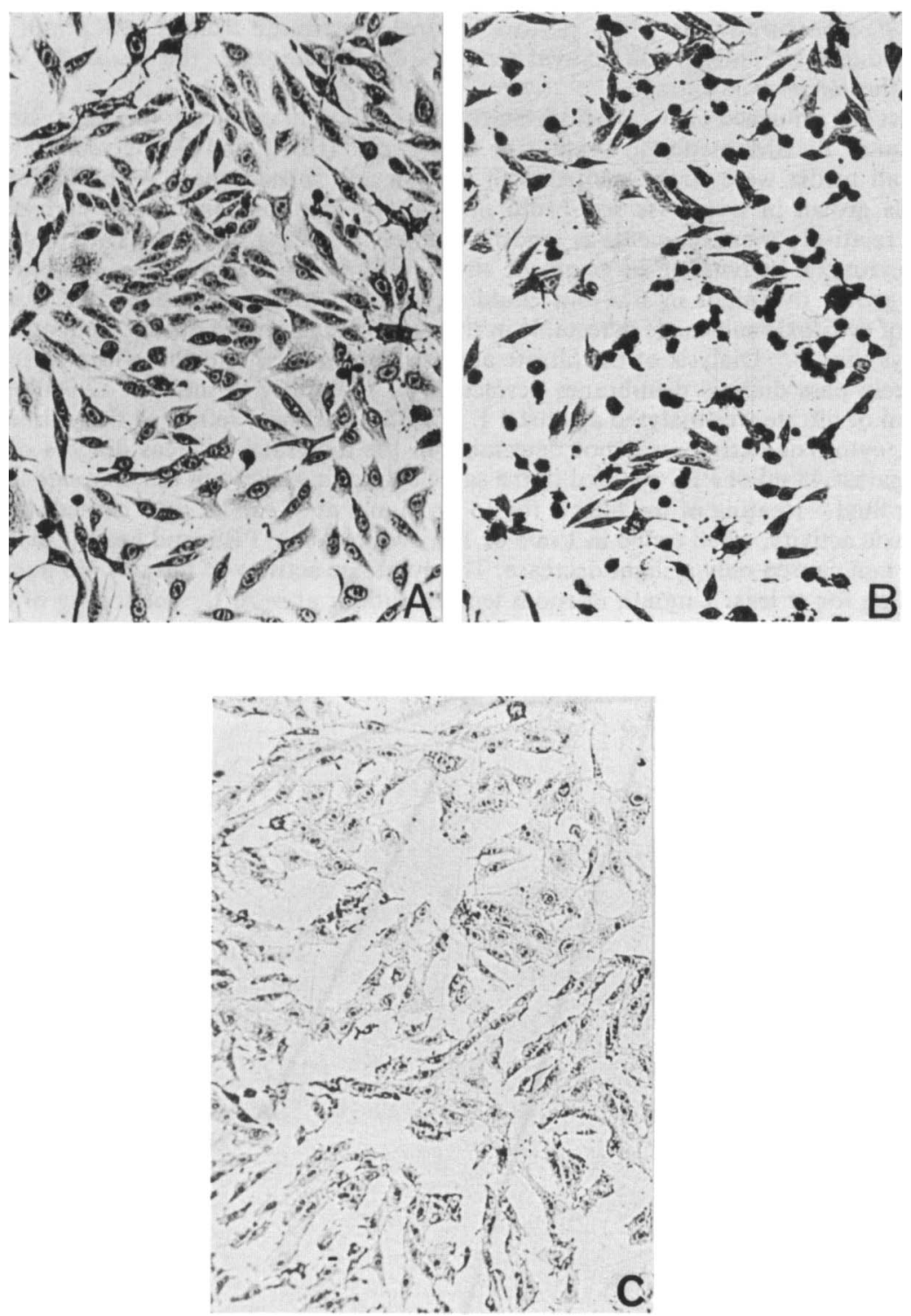

FIG. 1.-Vero-cell monolayer incubated: (A) for $48 \mathrm{~h}$ in BM medium (Shah et al., 1976) diluted 1 in 5 in PBS (control). $\times 100$; (B) for $48 \mathrm{~h}$ in culture filtrate from $B$. gingivalis strain W83 grown for 5 days in BM medium. $\times 100$; (C) for $24 \mathrm{~h}$ in culture filtrate, diluted 1 in 5 in PBS and final $p \mathrm{H} 6.2$, from $B$. melaninogenicus subsp. intermedius strain ATCC25261 grown in BM medium. $\times 100$.

on the cells could be detected after incubation for $16 \mathrm{~h}$ and increased during continued incubation for 2-4 days. The affected cells showed thick cell membranes, filamentous tendrils and rounding of the cell outline (fig. 1B). During prolonged incubation, more round cells were detected and these tended to float into the medium. Filtrates from all strains of $B$. gingivalis and $B$. asaccharolyticus caused an apparently similar morphological change in the Vero cells. In a 1 in 5 dilution, culture filtrates of most strains affected more than $70 \%$ of the Vero cells; when the culture filtrate was more dilute fewer cells were affected. The table shows that dilutions of filtrates from most strains of $B$. gingivalis had more toxic effect than 
those of B. asaccharolyticus. In a positive control, the filtrate from E. coli strain H10407, which produces LT enterotoxin, caused morphological changes to the Vero cells similar to those of the Bacteroides filtrates.

To test the influence of the medium on the production of cytotoxic products, strain W83 was cultured in BM medium, Trypticase Soy Broth (BBL) and Thioglycollate Medium (Difco); all media were supplemented with haemin and menadione. With culture filtrates from cells grown in trypticase soy broth or thioglycollate medium, fewer Vero cells were affected; relatively more filamentous tendrils and less rounding of the cells were observed.

The cytotoxic activity of $B$. gingivalis strain W83 was not detected in the filtrate from bacteria grown overnight in BM but could be detected after incubation for 2 days. The amount of cytotoxic substance detectable in the supernate increased during incubation from 2 to 13 days (fig. 2). Dialysis of the filtrate against PBS showed that the cytotoxic substances could freely pass dialysis membranes permeable to molecules of mol. wt 12000 and 3500; when $5 \mathrm{ml}$ of filtrate was dialysed against $1 \mathrm{~L}$ of PBS, which was refreshed three times at 24-h intervals, cytotoxic activity was not detectable in the dialysate, whereas dialysis of $5 \mathrm{ml}$ of filtrate against $45 \mathrm{ml}$ of PBS resulted in the same cytotoxic activity in the dialysate and in the dialysing fluid. Heating of the filtrate for 15 or $25 \mathrm{~min}$ at 37,50 or $70^{\circ} \mathrm{C}$ caused no decrease in cytotoxic activity, when tested in 1 in 5 or 1 in 10 dilution in PBS, and heating at $100^{\circ} \mathrm{C}$ for 10 or 25 min caused only a slight decrease. The cytotoxic activity of filtrates did not diminish on standing for at least 1 month at room temperature or at $-20^{\circ} \mathrm{C}$. The testing of cytotoxic

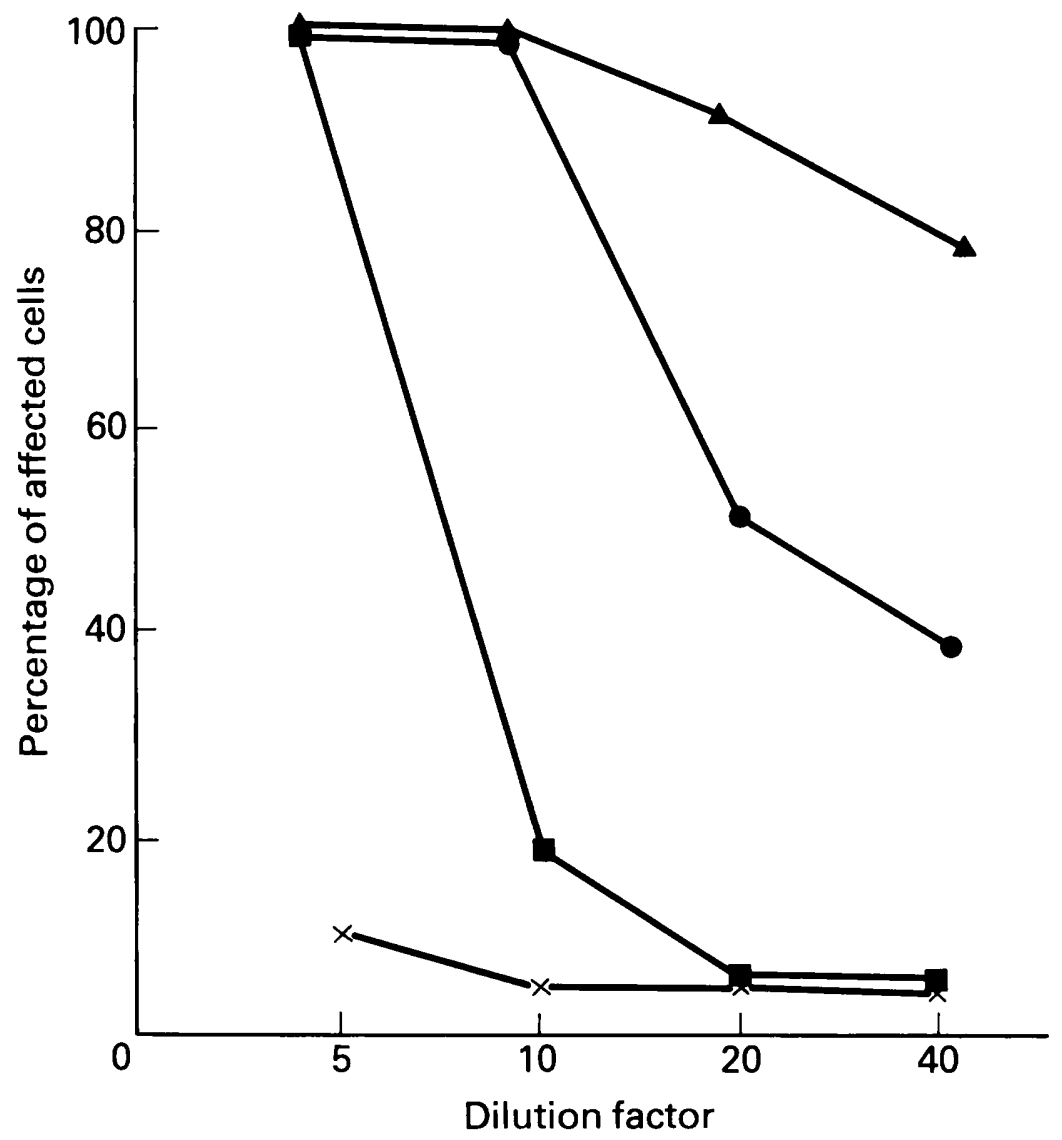

FIG. 2.-Morphological response of Vero cells to PBS dilutions of culture filtrate from $B$. gingivalis strain W83 grown in BM medium for 1 day $(\times-\times)$, 2 days $(-\square), 5$ days $(-\bullet)$ and 13 days $(\Delta-\Delta)$. 
activity was performed in aerobic conditions, suggesting that the cytotoxin is active in the presence of oxygen.

Dilutions of filtrates from strains of $B$. melaninogenicus subsp. melaninogenicus and $B$. melaninogenicus subsp. intermedius having a $p \mathrm{H}$ of less than 6.6 , were found to cause an effect on the Vero cells, but different from that of $B$. gingivalis and $B$. asaccharolyticus. After incubation with $B$. melaninogenicus filtrates the cells were swollen and their outline vague; the cytoplasm and the nuclei stained less intensely, despite the fact that staining conditions were the same (fig 1C). This effect was not observed when the $p \mathrm{H}$ of the culture filtrate was brought to 7.35 with $\mathrm{NaOH}$. Dilutions of unused $\mathrm{BM}$ medium acidified with $\mathrm{HCl}$ to a $p \mathrm{H}$ lower than 6.6 caused the same morphological changes of the Vero cells as did the culture filtrates of $B$. melaninogenicus.

\section{DisCUSSION}

Strains of B. gingivalis and B. asaccharolyticus produced a substance affecting Vero cells, and it could be detected in the filtrates of cultures grown for more than 1 day in BM medium. The morphological change caused by this cytotoxin was similar to the effect of culture filtrates of the LT enterotoxin of E. coli (Speirs et al., 1977). As far as we know, the existence of this bacteroides cytotoxin has not been reported before. The effect of culture filtrates of $B$. melaninogenicus on Vero cells can be explained by the relatively low $p \mathrm{H}$ alone.

The strain of $B$. gingivalis strain W83 has been shown to be very virulent in guinea-pigs and mice (Kastelein et al., 1981). The cytotoxin of this anaerobic bacterium was active in an aerobic atmosphere containing $5 \% \mathrm{CO}_{2}$; it was heat stable, had a mol. wt of less than 3500 and differed from the E. coli LT toxin, which is heat labile and has a mol. wt of more than 100000 (Speirs et al., 1977). The cytotoxin was detected in supernates of cultures grown into the late log phase or the stationary phase.

In general, filtrates from $B$. gingivalis strains were more cytotoxic than those of $B$. asaccharolyticus. This could of course be attributable to a higher concentration of the cytotoxin, differences in the cytotoxic substances or to the production of one or more additional cytotoxic substances by $B$. gingivalis.

Recent evidence suggests that $B$. gingivalis is more virulent than $B$. melaninogenicus and $B$. asaccharolyticus (Mayrand et al., 1980; van Steenbergen et al., in press). The role of the cytotoxin in disease remains to be elucidated. It is possible that this cytotoxin, which is active in vitro against mammalian cells, had an effect in vivo, for instance in adult periodontitis, in which $B$. gingivalis is thought to be important (Slots, 1979). It is not known whether the effects of culture filtrates from B. gingivalis and B. asaccharolyticus are caused by one or more substances, and this is the subject of current investigations.

We are grateful to Miss J. L. den Boer for assistance with the tissue cultures.

\section{REFERENCES}

Coykendall, A. L., Kaczmarek, F. S. and Slots, J. 1980. Genetic heterogeneity in Bacteroides asaccharolyticus (Holdeman and Moore 1970, Finegold and Barnes 1977, approved lists, 1980) and proposal of Bacteroides gingivalis sp. nov. and Bacteroides macacae (Slots and Genco) comb. nov. Int. J. syst. Bact. 30, 559.

FINEGOLD, S. M. 1977. Anaerobic bacteria in human disease. Academic Press, New York.

GibBons, R. J. AND MacDonald, J. B. 1961. Degradation of collagenous substrates by Bacteroides melaninogenicus. J. Bact., 81, 614.

HofSTAD, T. 1970. Biological activities of endotoxin from Bacteroides melaninogenicus. Archs oral Biol., 15, 343.

Kastelein, P., van Steenbergen, T. J. M., Bras, J. M. and de GraffF, J. 1981. An experimentally induced phlegmonous abscess by a strain of Bacteroides gingivalis in guinea pigs and mice. Antonie van Leeuwenhoek, 47, 1.

Mayrand, D., McBride, B. C., Edwards, T. and Jensen, S. 1980. Characterization of Bacteroides asaccharolyticus and B. melaninogenicus oral isolates. Can.J. Microbiol., 26, 1178. 
Shah, H. N., Williams, R. A. D., Bowden, G. H. and Hardie, J. M. 1976. Comparison of the biochemical properties of Bacteroides melaninogenicus from human dental plaque and other sites. J. appl. Bact. 41, 473.

SloTs, J. 1979. Subgingival microflora and periodontal disease. J. clin. Periodont., 6, 351.

SмITH, L. DS. 1975. The pathogenic anaerobic bacteria, 2nd ed., C. C. Thomas, Springfield, Illinois.

Speirs, J. I., Stavric, S. AND Konowalchuk, J. 1977. Assay of Escherichia coli heat-labile enterotoxin with Vero cells. Infect. Immun., 16, 617.

Spiegel, C. A., Hayduk, S. E., Minah, G. E. and Krywolap, G. N. 1979. Black-pigmented Bacteroides from clinically characterized periodontal sites. J. periodont. Res., 14, 376.

Tanner, A. C. R., Haffer, C., Bratthall, G. T., Visconti, R. A. and Socransky, S. S. 1979. A study of the bacteria associated with advancing periodontitis in man. J. clin. Periodont., 6, 278.

van SteEnbergen, T. J. M., de Soet, J. J. and de GraAfF, J. 1979. DNA base composition of various strains of Bacteroides melaninogenicus. F.E.M.S. Microbiol. Letts, 5, 127.

van Steenbergen, T. J. M., Vlaanderen, C. A. and de Graaff, J. 1981. Confirmation of Bacteroides gingivalis as a species distinct from Bacteroides asaccharolyticus. Int. J. syst. Bact. (in press). 